\title{
Impact of respiratory therapy in vital capacity and functionality of patients undergoing abdominal surgery
}

\author{
Impacto da fisioterapia respiratória na capacidade vital e na funcionalidade \\ de pacientes submetidos à cirurgia abdominal
}

\begin{abstract}
Shanlley Cristina da Silva Fernandes ${ }^{1}$, Rafaella Souza dos Santos ${ }^{1}$, Erica Albanez Giovanetti ${ }^{1}$, Corinne Taniguchi ${ }^{1}$, Cilene Saghabi de Medeiros Silva ${ }^{1}$, Raquel Afonso Caserta Eid ${ }^{1}$, Karina Tavares Timenetsky ${ }^{1}$, Denise Carnieli-Cazati ${ }^{1}$
\end{abstract}

\begin{abstract}
Objective: To evaluate the vital capacity after two chest therapy techniques in patients undergoing abdominal surgical. Methods: A prospective randomized study carried out with patients admitted to the Intensive Care Unit after abdominal surgery. We checked vital capacity, muscular strength using the Medical Research Council scale, and functionality with the Functional Independence Measure the first time the patient was breathing spontaneously (D1), and also upon discharge from the Intensive Care Unit (Ddis). Between D1 and Ddis, respiratory therapy was carried out according to the randomized group. Results: We included 38 patients, 20 randomized to Positive Intermittent Pressure Group and 18 to Volumetric Incentive Spirometer Group. There was no significant gain related to vital capacity of D1 and Ddis of Positive Intermittent Pressure Group (mean $1,410 \mathrm{~mL} \pm 547.2$ versus $1,809 \mathrm{~mL} \pm 692.3 ; p=0.979$ ), as in the Volumetric Incentive Spirometer Group $(1,408.3 \mathrm{~mL} \pm 419.1$ versus $1,838.8 \mathrm{~mL} \pm 621.3 ; p=0.889)$. We observed a significant improvement in vital capacity in D1 $(p<0.001)$ and Ddis $(p<0.001)$ and in the Functional Independence Measure $(p<0.001)$ after respiratory therapy. The vital capacity improvement was not associated with gain of muscle strength. Conclusion: Chest therapy, with positive pressure and volumetric incentive spirometer, was effective in improving vital capacity of patients submitted to abdominal surgery.
\end{abstract}

Keywords: Breathing exercises; Respiratory function tests; Respiratory muscles; Vital capacity

\section{RESUMO}

Objetivo: Avaliar a capacidade vital comparando duas técnicas de fisioterapia respiratória em pacientes submetidos à cirurgia abdominal. Métodos: Estudo prospectivo e randomizado realizado com pacientes admitidos em Unidade de Terapia Intensiva após cirurgia abdominal. Verificamos a capacidade vital, a força muscular por meio da escala do Medical Research Council e funcionalidade pela Medida de Independência Funcional no primeiro momento em que o paciente encontrava-se em respiração espontânea (D1) e na alta da Unidade de Terapia Intensiva (Dalta). Entre D1 e Dalta, foi realizada a fisioterapia respiratória, conforme o grupo randomizado. Resultados: Foram incluídos 38 pacientes, sendo 20 randomizados para Grupo Pressão Positiva Intermitente e 18 para o Grupo Incentivador Inspiratório a Volume. A capacidade vital entre o D1 e Dalta do Grupo Pressão Positiva Intermitente não teve ganho significativo (média de $1.410 \mathrm{~mL} \pm 547,2$ versus $1.809 \mathrm{~mL} \pm 692,3 ; p=0,979$ ), assim como no Grupo Incentivador Inspiratório a Volume $(1.408,3 \mathrm{~mL} \pm 419,1$ versus $1.838,8 \mathrm{~mL} \pm 621,3$; $p=0,889)$. Houve melhora significativa da capacidade vital no D1 $(p<0,001)$ e na Dalta $(p<0,001)$ e da Medida de Independência Funcional $(p<0,001)$ após a fisioterapia respiratória. A melhora da capacidade vital não apresentou relação com 0 ganho da força muscular. Conclusão: A fisioterapia respiratória, por meio de pressão positiva ou de incentivador inspiratório a volume, foi eficaz na melhora da capacidade vital em pacientes submetidos à cirurgia abdominal.

Descritores: Exercícios respiratórios; Testes de função respiratória; Músculos respiratórios; Capacidade vital

\section{INTRODUCTION}

Static lung volume measurement plays an important role in pulmonary functional assessment, indirectly providing lung elasticity, and establishing forced expiratory flows. ${ }^{(1)}$ Abdominal surgery, be it upper (above the umbilical line) or lower (below the umbilical line), leads to changes

\footnotetext{
'Hospital Israelita Albert Einstein, São Paulo, SP, Brazil.

Corresponding author: Denise Carnieli-Cazati - Avenida Albert Einstein, 627/701, building A, 5th floor - Morumbi - Zip code: $05652-900$ - São Paulo, SP, Brazil - Phone: (55 11) 3384-1143

E-mail: dcarnieli@yahoo.com.br

Received on: Aug 17, 2015 - Accepted on: May 6, 2016

Conflict of interest: none.

DOI: 10.1590/S1679-45082016A03398
} 
in respiratory mechanics, lung volume and capacity, oxygenation, and pulmonary defense mechanisms. Shallow breathing occurs as a result of pain, reducing lung volume and capacity, which may last for 7 to 14 days after the surgical procedure..$^{(2,3)}$

Respiratory therapy is helpful from the prevention to the treatment of pulmonary complications and comprises several techniques. ${ }^{(4)}$ These techniques are clinically significant and widely used because they increase functional residual capacity, ensure greater alveolar stability, and may be executed with or without mechanical devices. ${ }^{(5)}$

The objective of using of the incentive spirometer is to encourage the patient, through visual feedback, to sustain maximum inspiration. ${ }^{(6,7)}$ Despite the widespread use of the incentive spirometry, some systematic reviews suggested that this technique shows little evidence of benefits in the prevention of postoperative complications. ${ }^{(4)}$

Bi-level positive airway pressure, whether continuous or intermittent, has proven beneficial in prevention and treatment of pulmonary complications after heart surgeries. ${ }^{(8)}$ There are technical differences between bi-level positive continuous and intermittent airway pressures, because each of them acts in a specific way in the recovery of pulmonary function and respiratory mechanics. A review study showed the efficacy of continuous positive airway pressure, aiming to reduce the risk of pulmonary complications in patients undergoing abdominal surgery. ${ }^{(9)}$

However, the efficacy of respiratory therapy during postoperative abdominal surgery is still controversial. Pasquina et al. ${ }^{(10)}$ suggested that using routine respiratory therapy is unjustified, since few clinical trials show its effectiveness in prophylactic treatment. Nevertheless, Lawrence et al. ${ }^{(11)}$ stated that, in postoperative period of abdominal surgery, any pulmonary expansion technique is better than no prophylaxis.

It is known that respiratory therapy plays an important role in pulmonary rehabilitation, regardless of the technique employed. However, there are few studies that significantly express a comparison between techniques, such as the incentive spirometer and bi-level intermittent positive airway pressure during bedside patient care in the postoperative period of abdominal surgery (upper or lower).

\section{OBJECTIVE}

To assess vital capacity by comparing two respiratory therapy techniques in patients undergoing abdominal surgery.

\section{METHODS}

A randomized prospective analysis, in patients admitted to the adult and clinical-surgical Intensive Care Unit (ICU), in a private hospital. This study was approved by the Research Ethics Committee, under protocol number 214.411, CAAE: 12309513.6.0000.0071.

Patients included were over 18 years of age and underwent abdominal surgery, with or without pulmonary complications. We excluded patients with hemodynamic instability, previously diagnosed respiratory and/or neuromuscular diseases, and those who were uncooperative with physical therapy care.

Randomization was done by a draw to divide the patients into two groups: Positive Intermittent Pressure Group and Volumetric Incentive Spirometer Group.

Measurement of vital capacity (VC) was performed as described by the American Thoracic Society and by the European Respiratory Society, ${ }^{(12)}$ on the first day the patient started breathing spontaneously (D1) and on the day of discharge from the ICU (Ddis). Vital capacity was always checked at the beginning of treatment (D1 before and Ddis before) and at the end of respiratory therapy (D1 after and Ddis after) and 30 minutes after it (D1-30 and Ddis-30). Between days D1 and Ddis, the patients underwent conventional physiotherapy, as part of the institutional routine of the ICU physical therapy team, with lower limb free or assisted active exercises (according to the patient's condition), respiratory physiotherapy associated to upper limb free or assisted active exercises, assisted cough, and, if necessary, nasotracheal aspiration for bronchial hygiene. The respiratory therapy technique to be used with patients, according to the randomized group, was followed at all times.

Later, muscle strength was assessed through the Medical Research Council (MRC) scale ${ }^{(13-15)}$ and through the Functional Independence Measure (FIM) indicator. These measurements were collected on D1 and Ddis.

With regards to respiratory therapy at the time of patient assessment in the study, the following exercises were performed: lower limb free or assisted active exercises (according to the patient's condition); respiratory physiotherapy associated to upper limb free or assisted active exercises, assisted cough, and, if necessary, nasotracheal aspiration.

To wrap up the treatment according to randomization, bi-level intermittent positive airway pressure was performed in the Positive Intermittent Pressure Group, with the proper equipment for non-invasive, bi-level pressure mechanical ventilation, with inspiratory airway pressure and end-expiratory airway pressure. The (Ventilator iSleep, Breas ${ }^{\circledR}$, Mölnlycke, Sweden), was 
used in three series of ten repetitions and with pressures determined for each patient, according to their ideal tidal volume and following the mechanical ventilation consensus guidelines (tidal volume of $6 \mathrm{~mL} / \mathrm{kg}$ ), in accordance with equipment monitoring.

Volumetric incentive spirometer (Voldyne 5000, Hudson $\mathrm{RCI}^{\circledR}$, Tecate, México), was used by the Volumetric Incentive Spirometer Group, in three series of ten repetitions each.

Due to the lack of studies showing the benefits between the use of bi-level intermittent positive airway pressure techniques and volumetric incentive spirometer in postoperative patients who underwent abdominal surgery, it was possible to do the calculation of the sample based on the results of the first 10 cases assessed (pilot). Vital capacity variability was shown at 30 minutes of approximately $650 \mathrm{~mL}$, where there was an assumed difference of $600 \mathrm{~mL}$ between the groups, with $80 \%$ power and $95 \% \mathrm{IC}$. Thus, the required sample for the study was 19 patients per group.

Qualitative personal characteristics were described according to the groups, through absolute and relative frequencies, and the association between them was verified using $\chi^{2}$ or Fisher's exact tests, which was also used when the sample was insufficient for $\chi^{2}$ test.

Quantitative personal characteristics were described according to the groups through summary measures (mean, standard deviation, median, minimum and maximum), and compared amongst each other by Student's $t$ test or Mann-Whitney, in the absence of normal distribution of the variable, which was evaluated through Kolmogorov-Smirnov test.

Vital capacity results were described on the second day of assessment and at the moments to evaluate measurements during therapy (before, at the end of therapy, and 30 minutes after). MRC and FIM results were described as days of assessment and using summary measurements (mean, standard deviation, median, minimum and maximum).

The correlation between VC and MRC and FIM functionality scores was assessed in both groups, by calculating Pearson's correlations.

Tests were performed with a significance level of $5 \%$. Statistical analysis was done through the software Statistical Package for Social Sciences (SPSS), version 13.0.

\section{RESULTS}

The study comprised a sample of 38 individuals who were divided into two groups after randomization. The
Positive Intermittent Pressure Group was formed by 20 individuals, and the Volumetric Incentive Spirometer Group by 18 individuals. The sample did not show significant difference between age, total days at the ICU, and total days of hospital stay between the groups.

The groups were homogenous and did not show significant difference between their characteristics, such as gender, personal background, and respiratory complications. The only significant difference was in the fact that the Positive Intermittent Pressure Group showed a higher number of upper abdominal surgeries $(80 \%)$, and the Volumetric Incentive Spirometer Group showed a higher number of lower abdominal surgeries $(83.3 \%)(\mathrm{p}<0.001)$. However, the type of abdominal surgery was not a criterion for randomization interference (Table 1).

Table 1. Description of the sample

\begin{tabular}{|c|c|c|c|}
\hline Variables & $\begin{array}{l}\text { Positive } \\
\text { Intermittent } \\
\text { Pressure } \\
\text { Group }\end{array}$ & $\begin{array}{l}\text { Volumetric } \\
\text { Incentive } \\
\text { Spirometer } \\
\text { Group }\end{array}$ & p value \\
\hline Age (years), ${ }^{*}$ mean (SD) & $58.70(15.9)$ & $63.67(15.6)$ & 0.340 \\
\hline Gender $^{\dagger}-\mathrm{n}(\%)$ & & & 0.703 \\
\hline Female & $9(45)$ & $7(38.9)$ & \\
\hline Male & $11(55)$ & $11(61.1)$ & \\
\hline Smoking $^{\dagger}-n(\%)$ & $1(5)$ & $1(5.6)$ & $>0.999$ \\
\hline \multicolumn{4}{|l|}{ Past history ${ }^{\dagger}-\mathrm{n}(\%)$} \\
\hline Hypertension & $4(20)$ & $8(44.4)$ & 0.106 \\
\hline $\mathrm{DM}$ & $4(20)$ & $5(27.8)$ & 0.709 \\
\hline Type of abdominal surgery ${ }^{\dagger}-n(\%)$ & & & $<0.001$ \\
\hline Higher & $16(80)$ & $3(16.7)$ & \\
\hline Lower & $4(20)$ & $15(83.3)$ & \\
\hline Respiratory complications ${ }^{\dagger}-n(\%)$ & & & $>0.999$ \\
\hline Atelectasis & $3(15)$ & $0(0)$ & 0.232 \\
\hline Pleural effusion & $3(15)$ & $0(0)$ & 0.232 \\
\hline Length of stay at ICU (days) $)^{\ddagger}$ - median (max-min) & $2.75(1-7)$ & $2.44(1-4)$ & 0.696 \\
\hline Length of stay (days) $)^{\ddagger}$ - median (max-min) & $10(5-88)$ & $12(5-27)$ & 0.497 \\
\hline
\end{tabular}

Correlation of VC measurements between the Positive Intermittent Pressure Group and the Volumetric Incentive Spirometer Group did not show significant difference $(p=0.969)$. However, in regards to the correlation between each moment, there was significant difference in VC measurements (Figure 1). There was significant gain between D1 before and D1 after $(\mathrm{p}<0.001)$ and D1 before and D1-30 ( $<<0.001)$. However, there was no significant difference between D1 after and D1-30 $(p>0.999)$, or between D1-30 and Ddis before $(p=0.308)$. There was significant VC improvement between Ddis before and Ddis after $(\mathrm{p}<0.001)$. 
A

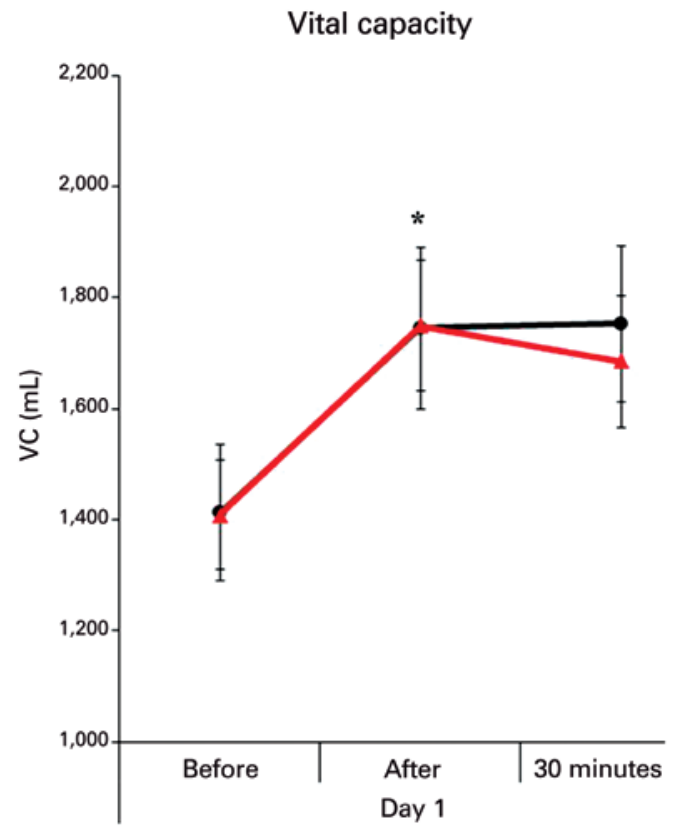

IPPB

Volumetric incentive spirometer

B

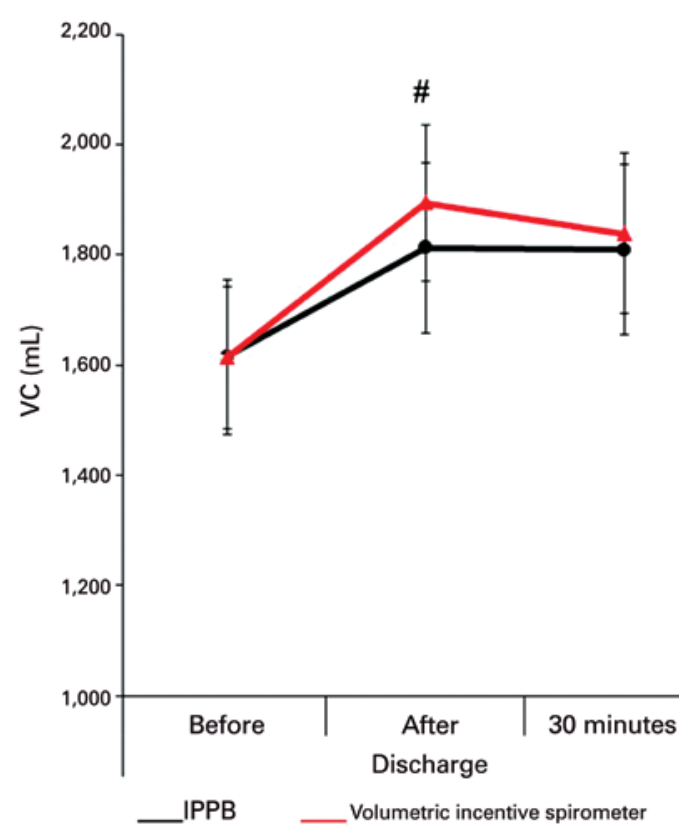

*Vital capacity was significantly higher after therapy than before, $p<0.001$. \#Vital capacity was significantly higher after therapy than before, $p<0.001$.

VC: vital capacity; IPPB: intermittent positive pressure breathing.

Figure 1. Vital capacity measurements in each (D1) and (Ddis) of the patient. (A) Vital capacity measurements in the first therapy session.

(B) Vital capacity measurements in the last therapy session at the Intensive Care Unit

After the surgical procedure, all patients presented $\mathrm{VC}$ below the predicted lower limit. Even with significant gain after respiratory therapy, $\mathrm{VC}$ measurements remained below the predicted lower limit ${ }^{(1)}$ (Table 2).
Table 2. Vital capacity measurement in the first (D1) and last (Ddis) therapy session at the Intensive Care Unit, and predicted lower limit of vital capacity in the Positive Intermittent Pressure Group and Volumetric Incentive Ipirometer Group

\begin{tabular}{lccc}
\hline Variables & $\begin{array}{c}\text { Positive } \\
\text { Intermittent } \\
\text { Pressure Group }\end{array}$ & $\begin{array}{c}\text { Volumetric } \\
\text { Incentive } \\
\text { Spirometer Group }\end{array}$ & $\begin{array}{c}\mathbf{p} \\
\text { value }\end{array}$ \\
\hline D1 before*, mL - mean (SD) & $1,412.50(547.2)$ & $1,408.33(419.1)$ & 0.979 \\
Ddis 30*, mL - mean (SD) & $1,809.00(692.3)$ & $1,838.89(621.3)$ & 0.889 \\
Predicted lower limit VC* & $3,094.35(769.9)$ & $2,789.33(543.4)$ & 0.171 \\
$\mathrm{~mL}$ - mean (SD) & & &
\end{tabular}

*Student's $t$ test.

SD: standard deviation; VC: vital capacity

With regards to measurements of FIM (Figure 2) and MRC (Figure 3) scales, no significant difference was found between the two groups $(p=0.204$ and $p=0.160$, respectively). However, when comparing them between D1 and Ddis, a significant increase was found in both FIM $(p<0.001)$ and MRC $(p=0.003)$.

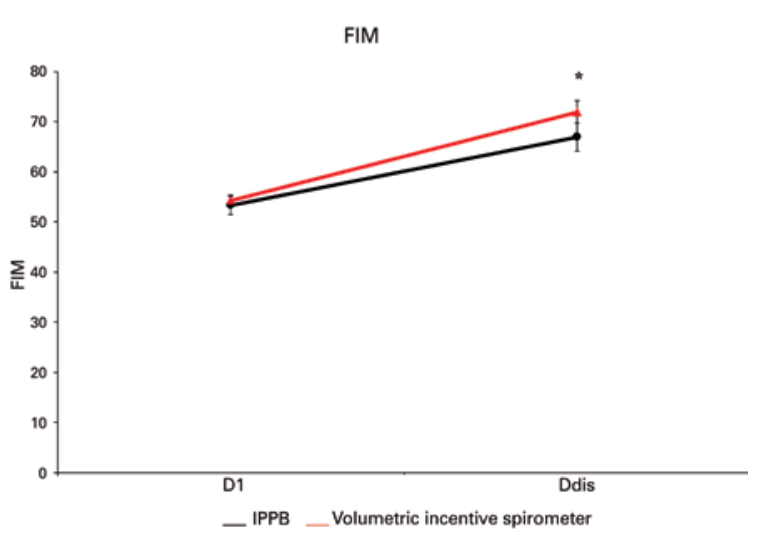

*Ddis is significantly higher than at D1, $p<0.001$

FIM: functional independence measure; IPPB: intermittent positive pressure breathing.

Figure 2. Functional Independence Measure performed on the first (D1) and last (Ddis) respiratory therapy session before discharge from the intensive care unit

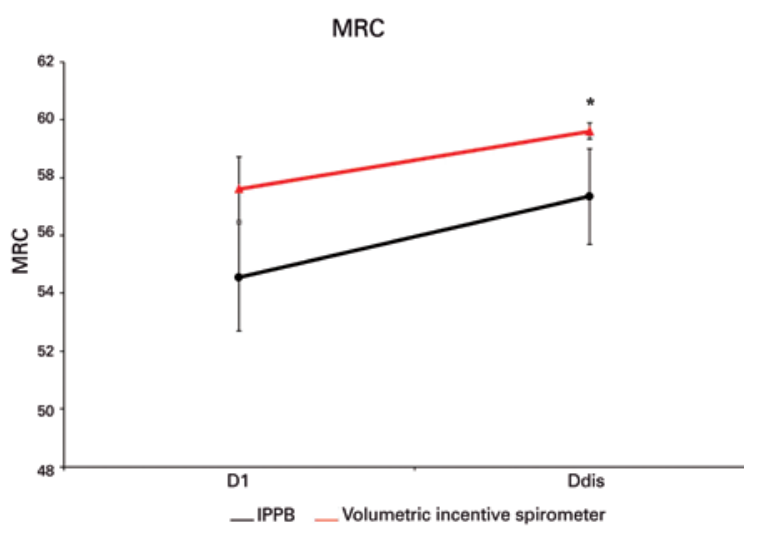

*Ddis is significantly higher than at D1, $\mathrm{p}=0.003$

MRC: medical research council.; IPPB: intermittent positive pressure breathing.

Figure 3. Assessment of overall muscle strength performed on the first (D1) and last (Ddis) respiratory therapy session before discharge from the intensive care unit 
No correlation was found between VC and functionality measurements FIM and muscle strength MRC, on D1 ( $\mathrm{r}=-0.094$ and $\mathrm{r}=0.211 ; \mathrm{p}>0.05)$ or on Ddis $(r=0.265$ e $r=0.189 ; p>0.05)$, respectively.

\section{DISCUSSION}

Upper or lower abdominal surgery has a great impact on patients' pulmonary mechanics, with a direct influence on lung capacity and volume. ${ }^{(16)}$ In our sample, all patients arrived at the ICU with VC below the predicted lower limit and were more prone to pulmonary complications. Nonetheless, even though these measurements were below the lower limit, there was significant gain in $\mathrm{VC}$ after respiratory therapy.

Respiratory therapy, with volumetric incentive spirometer or intermittent positive pressure, is efficient with regards to $\mathrm{VC}$ gain for patients undergoing abdominal surgery. In both the Positive Intermittent Pressure Group and the Volumetric Incentive Spirometer Group, VC gain was observed when comparing the first measurement before respiratory therapy and the last measurement before discharge from ICU.

The Positive Intermittent Pressure Group was formed by a higher percentage of upper abdominal surgeries, most of which were liver transplants, whereas the Volumetric Incentive Spirometer Group had a prevalence of lower abdominal surgeries. Although the groups did not present significant differences between them, literature shows that upper abdominal surgeries tend to trigger more pulmonary complications. . $^{(2,3,10)}$ However, in this study, neither group showed significant pulmonary complications.

Marques et al. ${ }^{(17)}$ stated that the volumetric incentive spirometer is better than the flow incentive spirometer, because it promotes a more efficient respiratory pattern, that is, a predominantly abdominal breathing with superior inspiratory time and reduced respiratory muscle overload, which brings more comfort to the patient and more efficiency during the exercise. Respiratory therapy is important in the ICU, and, among all the techniques used in that environment, intermittent positive pressure appears as a device that may help increase lung volumes and optimize gas exchange..$^{(18,19)}$

Regardless of the technique or device here employed, there is evidence that respiratory therapy is beneficial and efficient when applied to bed-ridden patients with respiratory mechanics alterations triggered by surgical procedures.

In our results, the most significant gain happened on the first day of therapy, when we observed a significant difference between D1 before and D1 after. Between
D1 after and D1-30, there was a small drop in VC, which was still higher than D1 before. This suggests that respiratory therapy in early postoperative stages may prevent VC from staying too low and, consequently, prevent other pulmonary complications. Despite a small decrease after therapy, there is still gain in pulmonary function. However, when comparing D1 to Ddis, the gain between the two moments was not as significant as on D1.

Our sample showed the sustained gain in VC, suggesting that respiratory therapy improves the patient's VC and helps maintain that gain throughout time. This is an extremely important point, since these patients present with altered respiratory mechanics and need respiratory and functional re-education in the postoperative period.

In relation to patient functionality, rehabilitation was efficient in the gain of these measurements. Initially, the patients showed decreased overall muscle strength, with consequent restriction of daily functions and, after rehabilitation, overall muscle strength showed significant improvement. Therefore, in order to minimize risk of immobility caused by postoperative pain or complications, respiratory therapy promotes increase of muscle strength and improves functionality in activities of daily life.

Muscle strength and functionality are directly related. When a patient presents reduced muscle strength, decrease or loss of functionality occurs as a consequence. ${ }^{(18)}$ Correlating these two important items to pulmonary function, we observed that MRC and FIM gains did not have significant relation to $\mathrm{VC}$. This suggests a gain in overall muscle strength with consequent improvement of patient's functionality, but also that this improvement is not directly related VC improvement. This has us considering that the improvement in $\mathrm{VC}$ was related to respiratory function optimization with lung volume and capacity increase, and not to the gain of overall muscle strength.

Ferreira et al. ${ }^{(20)}$ stated that with respiratory therapy after abdominal surgeries, such as cholecystectomy, the patient presents improvements in respiratory mechanics and also gains in functionality and quality of life, due to muscle strength improvement and cardiorespiratory fitness.

A possible limitation of this study was due to the short ICU stay as a result of high patient turnover. However, patients undergoing abdominal surgery may present changes in ventilatory mechanics immediately after surgery, which prompts pulmonary complications. Another limitation was the authorization by the medical staff to use of positive pressure in the postoperative period; however the proposed goal was reached. 


\section{CONCLUSION}

Respiratory therapy done with bi-level intermittent positive airway pressure and/or volumetric incentive spirometer benefited the patients in the postoperative period of abdominal surgery, improving vital capacity. The was no correlation between vital capacity gain and the Functional Independence Measure and the Medical Research Council scales, but the patients presented increased strength and functionality separately. This suggested that respiratory therapy aids in overall muscle strength improvement, with enhanced functionality, bringing more independence to the patients in their activities of daily life.

\section{REFERENCES}

1. Barreto SS. Volumes pulmonares. J Pneumol. 2002;28(Supl 3):83-94.

2. Cardim ES. Avaliação respiratória nos períodos pré e pós-operatórios em doentes submetidos à cirurgia abdominal eletiva por afecção digestiva [tese]. São Paulo: Escola Paulista de Medicina; 1991.

3. Dias CM, Plácido TR, Ferreira MF, Guimarães FS, Menezes SL. Inspirometria de incentivo e breath stacking: repercussões sobre a capacidade inspiratória em indivíduos submetidos à cirurgia abdominal. Rev Bras Fisioter. 2008;12(2):94-9.

4. Yamaguti WP, Sakamoto ET, Panazzolo D, Peixoto CC, Cerri GG, Albuquerque AL. Mobilidade diafragmática durante espirometria de incentivo orientada a fluxo e a volume em indivíduos sadios. J Bras Pneumol. 2010;36(6):738-45.

5. Tomich GM, França DC, Diniz MT, Britto RR, Sampaio RF, Parreira VF. Efeitos de exercícios respiratórios sobre o padrão respiratório e movimento toracoabdominal após gastroplastia. J Bras Pneumol. 2010;36(2):197-204.

6. Wattie J. Incentive spirometry following coronary artery bypass surgery. Physiotherapy. 1998;84(10):508-14.

7. Marini JJ, Rodriguez RM, Lamb VJ. Involuntary breath-stacking. An alternative method for vital capacity estimation in poorly cooperative subjects. Am Rev Respir Dis. 1986;134(4):694-8.
8. Müller AP, Olandoski M, Macedo R, Costantini C, Guarita-Souza LC. [Comparative study between intermittent (Müller Reanimator) and continuous positive airway pressure in the postoperative period of coronary artery bypass grafting]. Arq Bras Cardiol. 2006;86(3):232-9. Portuguese.

9. Tzani P, Chetta A, Olivieri D. Patient assessment and pulmonary side-effects in surgery. Curr Opin Anesthesiol. 2011;24(1):2-7. Review.

10. Pasquina $P$, Tramèr MR, Granier JM, Walder B. Respiratory physiotherapy to prevent pulmonary complications after abdominal surgery: a systematic review. Chest. 2006;130(6):1887-99. Review.

11. Lawrence VA, Cornell JE, Smetana GW; American College of Physicians. Strategies to reduce postoperative pulmonary complications after noncardiothoracic surgery: systematic review for the American College of Physicians. Ann Intern Med. 2006;144(8):596-608. Review.

12. American Thoracic Society/European Respiratory Society. ATS/ERS Statement on respiratory muscle testing. Am J Respir Crit Care Med. 2002;166(4):518-624.

13. Riberto M, Miyazaki MH, Jorge Filho D, Sakamoto H, Battistella LR. Reprodutibilidade da versão brasileira da medida de independência funcional. Acta Fisiátrica. 2001;8(1):45-52.

14. Kendall FP, McCreary EK, Provance PG. Músculos: provas e funções. 4a ed São Paulo: Manole; 1995. p.189-205.

15. Schweickert WD, Hall J. ICU-acquired weakness. Chest. 2007;131(5):1541-9. Review.

16. Trevisan ME, Soares JC, Rondinel TZ. Efeitos de duas técnicas de incentivo respiratório na mobilidade toracoabdominal após cirurgia abdominal alta. Fisioter Pesqui. 2010;17(4):322-6.

17. Marques $\mathrm{CL}$, Faria IC. Terapia incentivadora da inspiração: uma revisão das técnicas de espirometria de incentivo a fluxo e a volume e o Breath-Stacking. Rer Bras Prom Saude. 2009;22(1):55-60.

18. França EE, Ferrari F, Fernandes P, Cavalcanti R, Duarte A, Martinez BP, et al. Fisioterapia em pacientes críticos adultos: recomendações do Departamento de Fisioterapia da Associação de Medicina Intensiva Brasileira. Rev Bras Ter Intensiva. 2012;24(1):6-22.

19. Pazzianotto-Forti EM, Laranjeira TL, Silva BG, Montebello MI, Rasera Jr I. Aplicação da pressão positiva contínua nas vias aéreas em pacientes em pós-operatório de cirurgia bariátrica. Fisioter Pesq. 2012;19(1):14-9.

20. Ferreira LL, Alves AS. Fisioterapia respiratória no pré-operatório de colecistectomia. ABCS Health Sci. 2013;38(1):47-51. 